\title{
Food Offer, Chronic Diarrhea and Preparedness to Alimentary Diabetes from the Second Year of Life Onwards
}

\author{
Mario Ciampolini ${ }^{1} \&$ Lorenzo Borselli ${ }^{1}$ \\ ${ }^{1}$ Preventive Gastroenterology, Department of Paediatrics, Università di Firenze, 50132 Florence, Italy \\ Correspondence: Mario Ciampolini, Università di Firenze, 50132 Florence, Italy. Tel: 39-055-215-744 E-mail: \\ mlciampolini@fastwebnet.it
}

Received: September 30, 2015 Accepted: October 31, 2015 Online Published: December 21, 2015

doi:10.5539/jfr.v5n1p18 URL: http://dx.doi.org/10.5539/jfr.v5n1p18

\begin{abstract}
Background: We have worked out an alimentary behaviour based on a meal- after -meal individual limit of energy intake (IHMP). We have then studied the energy intake, the pre-prandial blood glucose concentration (blood glucose, BG) and the body weight of a group of children with chronic not specific diarrhea. Finally we have added BG tolerance tests to clinically healthy adults in order to ascertain a possible association between IHMP and insulin sensitivity, should functional disorders or overweight problems arise.
\end{abstract}

Objective: With the present study we want to verify if mothers are capable of maintaining the IHMP and low pre-prandial BG levels in the eight years following the initial training, also in absence of diarrhea relapses. In adults the IHMP is associated to a good insulin sensitivity and this fact should be taken into consideration in order to reduce the increase of non - trasmissible deseases in the Western World.

Methods: We recruited children with not specific chronic diarrhea (bowel functional disorders) and selected randomly 53 mother-child pairs as the control group and 100 to be trained. Mothers were taught both how to recognise the correspondence between the individual manifestations of hunger and the BG concentration (Initial Hunger Meal Pattern, IHMP). The aim was to get low BG levels before each meal, and, thanks to the skill acquired, to stop the insulin resistance. The energy intake and the pre-prandial BG levels were reported in weekly diaries while the symptoms were recorded through structured interviews after 3 and 6 months and after $2,4,6,8$ years.

Results: Energy intake reductions were significantly larger in trained than in control subjects at all 6 surveys after recruitment $(\mathrm{P}<0.04$ to $<0.0001)$ although growth was similar, Diarrhea and vomiting significantly dropped both in the trained group and in the control one compared to the beginning of the research. Larger reductions from base values in days with diarrhea in trained children (compared with controls) were found for the three initial months and in drug administration at the surveys after 2 years and after 8 years

Conclusion: Chronic non-specific diarrhea of the second year of life is associated with high energy intake and high pre-prandial BG for incomplete exhaustion of previous energy intake. In adults, this habit is associated with fattening/insulin resistance.

Keywords: energy balance, energy intake, even energy balance, blood glucose, even blood glucose

\section{Introduction}

According to many studies (Ciampolini et al., 1990, 2006, 2010, 2010, 2011, 2012, 2013, 2013, 2013, 2014; Fisher \& Birch., 2002), nutrients disappearing from circulation may settle either on the liver or on the adipose tissue or being burned out. The storage is however reversible because it is strictly related to a high blood glucose concentration (BG). The total exhaustion of food added in previous meals is due to oxidation or body growth and coincides with the arousal of Initial Hunger $(\mathrm{IH})$ and a low pre-prandial BG $(76.6 \pm 3.7 \mathrm{mg} / \mathrm{dl}$ in sedentary people) (Ciampolini et al., 1990, 2012, 2013). This is a low energy level available both in blood and in all tissues. A too low energy level is associated to persistent hunger which is not acceptable or admissible in a healthy alimentation. Higher values would allow to refrain reasonably from food. Therefore absence of IH arousal indicates an incomplete expenditure of nourishments added in the previous meal (see Re-education). This statement may sound as an obvious axiom to be used as a valid ground for human alimentation. Yet we want to show that this obvious principle is useful since infancy to prevent fattening/insulin resistance. 
We have chosen to consider the phases of both energy expenditure and energy supply (at meals) in adults as well as in children. The IH (Ciampolini et al., 1990, 2006, 2010, 2010, 2011, 2012, 2013, 2013, 2013, 2014; Fisher \& Birch, 2002) appeared after suspension of meals as a sensation, i.e. as a subjective (psychic) event in adults and as a physical manifestation (individual, according to the mothers' evaluation) in children. In the single individual this event coincided constantly with the same BG. IH acquired an objective value through this demonstration and three or four IH arousals per day were useful to achieve an even energy balance meal after meal.

In absence of visual, verbal or smell suggestions, the child's manifestation of hunger solicited mothers to supply energy (Fisher et al., 2002; Ciampolini et al., 2013, 1994, 2000; Cooper et al., 2014; de Graaf et al., 2004). The onset of initial hunger coincided with an identical reproducible low BG (condition of reduced availability of energy in circulation i.e. in all tissues). After pre-prandial measurements 3 times a day for a period of two weeks the BG level was easily and accurately recognized (Ciampolini et al., 2006; Ciampolini et al., 1990; Ciampolini 2012; Ciampolini et al., 2013). The following month in the hospital laboratory, the infants and the mothers for their children were able to estimate BG, just before breakfast, with an error range of only $2-4 \mathrm{mg} / \mathrm{dL}$ compared to the measurements carried out by means of the autoanalyzer (Ciampolini et al., 2006, 1990, 2012, 2013). The adults and the mothers for their children were therefore capable of distinguishing the hunger due to suspension of meals (IH) from conditioned hunger. This implied the acknowledgement of the total expenditure of the energy taken in the previous meal. Further drops would have implied a hunger endurance, which is not admissible in a normal healthy alimentation.

In children affected by chronic diarrhea the relapses occurred during a rapid increase of energy administration. This observation prompted us to assume that the mean or the standard deviation of calorie supply was excessive (Ciampolini et al., 1990). Without bothering the child we could reduce feeding up to the time of the onset of demand (Initial hunger) and then give the child the energy amount needed to cover (with no demand) the gap of the following 3 or 4 hours i.e. up to the following meal (Ciampolini et al., 1990). From this reasoning, originated the Initial Hunger Meal Pattern (IHMP), a type of alimentation based on the rythm of initial hunger. The IHMP led to the rapid resolution of chronic diarrhea and prevented recurrences both in adults and in children in randomly controlled studies (Ciampolini et al., 2010, 2006, 2011, 2010, 2011, 2012, 1990, 2012, 2013).

The IHMP worked the same way with adults, but the effect on symptoms was secondary compared to a much more important achievement. In the course of our research, adults were trained to take food at the onset of initial hunger (IHMP). Three times a day 89 adults filled seven -day diaries with pre-prandial BG measurements. They were put trough a glucose load test (OGTT) (Ciampolini et al., 2011) After five months 15 turned out to be not compliant, 40 noticed reduced mean BG levels and developed a higher insulin sensitivity by OGTT. In 34 subjects the mean BG was already low at their recruitment and remained the same after adopting the IHMP (Ciampolini et al., 2011, 2012). In conclusion expending the total energy taken with the previous meal entails both a low mean BG before meals $(76.6-3.7 \mathrm{mg} / \mathrm{dl})$ and a high level of insulin sensitivity. The IHMP reduced the insulin resistence by a third on the basis of the reduced area of the glucose load curve (OGTT). The IHMP reduced also the insulin index and the insulinogenic index (Ciampolini et al., 2011, 2010, 1994, 2000), the energy intake, the weekly mean BG, the glycated haemoglobin in both overweight and insulin resistant normal weight subjects. On the contrary the insulin sensitive subjects with a normal weight were not affected (Ciampolini et al., 2010, 2011, 2010, 2012, 2013). High insulin sensitivity is an important target to achieve for a child we want to train to become a healthy adult.

After teaching the IHMP (Ciampolini et al., 1990, 2012, 2013) we noticed that diarrhea relapses decreased with a significant, greater difference from control children in the early days. In our new current study we want to verify whether the diarrhea stopping is going to continue in the 8 following years and if not, whether it may be due to an adjustment of the energy intake pattern or rather because, after the 3 first years of age children become refractory to diarrhea or finally because diarrhea evolves into other symptoms like vomiting, abdominal aches, acne or cephalea.

We trained 100 mothers of as many two-year old children to recognize the initial hunger (Ciampolini et al., 1990, $2012,2013)$ as a hint of the total consumption of the previous meal and as the best time to initiate the following. Follow - up studies covering a period of more than ten years showed that this alimentation pattern is associated to a cut of more than $20 \%$ of energy intake. We want to verify if the 100 trained children (Ciampolini et al., 1990, 2012, 2013) succeed in maintaining the acquired skill (IHMP) and if they suffer from vomiting and diarrhea for fewer days than the 53 not trained children. With this target in mind we selected 153 children with non- specific chronic diarrhea symptoms and followed them up for 8 years. 


\section{Materials and Methods}

\subsection{Participants}

The Paediatric Gastroenterology Unit of the University of Florence recruited 153 mother-child pairs as it had occurred in a previous research carried out from 1986 to 1992 (Ciampolini et al., 1990, 2012, 2013). At their recruitment children were 6 - 36 months old (Table 1) with symptoms of intestinal functional disorders (nonspecific chronic diarrhea) (Ciampolini et al., 1990, 2012, 2013), though clinically healthy. We excluded allergies by measuring the total IgEs in the blood plasma and by using Paper Radio Immuno Sorbent tests. We examined every child's feces to seek parasites, viruses or pathogenic bacteria. Positive subjects were excluded. The reactive protein $\mathrm{C}$ was normal. According to the Helsinky Declaration the research was approved by the ethic Board of the University. Informed consent was obtained for every child. Initially a list assigned 2 children at random to the trained group or one to the control one (in the proportion of 2 to 1 following Armitage's list of even or odd numbers) (Gavin, 2001 ).

Table 1. Time from recruitment, Age, Body weight, Weight per age, Energy intake and Mean weekly blood glucose $(\mathrm{BG}, \mathrm{Mean} \pm \mathrm{SD})$

\begin{tabular}{|c|c|c|c|c|c|c|c|c|c|c|}
\hline \multicolumn{5}{|c|}{ CONTROL } & \multicolumn{6}{|c|}{ TRAINED } \\
\hline Survey & Age (m) & $\begin{array}{l}\text { Energy } \\
\mathrm{Cal} / \mathrm{kg}(4)\end{array}$ & $\begin{array}{l}\text { Weight } \\
(\mathrm{kg})\end{array}$ & $\begin{array}{l}\text { Weight }(\%) \\
(1)\end{array}$ & Age (m) & $\begin{array}{l}\text { Energy } \mathrm{Cal} / \mathrm{kg} \\
(3,4)\end{array}$ & $\begin{array}{l}\text { BG } \mathrm{mg} / \mathrm{dL} \\
(5)\end{array}$ & $\begin{array}{l}\text { Weight } \\
(\mathrm{kg})\end{array}$ & $\begin{array}{l}\text { Weight } \\
(\%, 1,2)\end{array}$ & Survey \\
\hline Base & $18.5 \pm 7.2$ & $95 \pm 19.1$ & $9.7 \pm 2.1$ & $87.4 \pm 15.0$ & $17,7 \pm 6.7$ & $100 \pm 22.2$ & $89,6 \pm 12.6$ & $10.1 \pm 2.0$ & $90.2 \pm 12.1$ & Base \\
\hline $3 \mathrm{~m}$. & $21.4 \pm 7.0$ & $93 \pm 17.3$ & $10.6 \pm 1.6$ & $90.6 \pm 8.7$ & $22.4 \pm 10.3$ & $71 \pm 19.8$ & $81,3 \pm 5.8$ & $11.0 \pm 2.5$ & $92.2 \pm 12.1$ & $3 \mathrm{~m}$. \\
\hline $6 \mathrm{~m} .$. & $24.9 \pm 6.1$ & $94 \pm 18.2$ & $11.3 \pm 1.9$ & $89.0 \pm 10.9$ & $27.9 \pm 10.8$ & $71 \pm 20.3$ & $77.1 \pm 7.5$ & $12.2 \pm 2.5$ & $94.4 \pm 12.2$ & $6 \mathrm{~m}$. \\
\hline $2 \mathrm{y}$. & $42.9 \pm 10.4$ & $77 \pm 19.5$ & $15.7 \pm 5,8$ & $97.6 \pm 10.4$ & $42.0 \pm 13.8$ & $64 \pm 16.2$ & $78,7 \pm 6.5$ & $14.8 \pm 3.7$ & $94.4 \pm 13.5$ & $2 \mathrm{y}$. \\
\hline $4 \mathrm{y}$. & $65.2 \pm 29.0$ & $70 \pm 17.5$ & $19.2 \pm 3.5$ & $100.6 \pm 17.0$ & $64.7 \pm 18.5$ & $62 \pm 17.6$ & $81.0 \pm 7.9$ & $18.6 \pm 4.0$ & $97.9 \pm 13.4$ & $4 \mathrm{y}$. \\
\hline $6 \mathrm{y}$. & $86.7 \pm 15.2$ & $59 \pm 15.2$ & $24.0 \pm 5.8$ & $103.0 \pm 18.8$ & $87.4 \pm 10.1$ & $53 \pm 14.0$ & $80,4 \pm 7.2$ & $23.9 \pm 5.1$ & $102.1 \pm 16.7$ & $6 \mathrm{y}$. \\
\hline $8 \mathrm{y}$. & $112.6 \pm 11.3$ & $48 \pm 14.3$ & $30.7 \pm 8.5$ & $102.6 \pm 25.0$ & $111.8 \pm 11.6$ & $44 \pm 11.5$ & $83,1 \pm 8.5$ & $31.0 \pm 7.3$ & $104.6 \pm 20.6$ & $8 \mathrm{y}$. \\
\hline Survey & Age (m.) & $\begin{array}{l}\text { Energy } \\
\mathrm{Cal} / \mathrm{kg}(4)\end{array}$ & $\begin{array}{l}\text { Weight } \\
(\mathrm{kg})\end{array}$ & $\begin{array}{l}\text { Weight }(\%) \\
(1)\end{array}$ & Age (m.) & $\begin{array}{l}\text { Energy } \mathrm{Cal} / \mathrm{kg} \\
(3,4)\end{array}$ & $\begin{array}{l}\text { BG } \mathrm{mg} / \mathrm{dL} \\
(5)\end{array}$ & $\begin{array}{l}\text { Weight } \\
(\mathrm{kg})\end{array}$ & $\begin{array}{l}\text { Weight } \\
(\%, 1,2) \\
\end{array}$ & Survey \\
\hline \multicolumn{5}{|c|}{ CONTROL } & \multicolumn{6}{|c|}{ TRAINED } \\
\hline
\end{tabular}

(1) Significant increases over base, except at the $3 \mathrm{~m}$. survey $(\mathrm{P}<0.001)$.

(2) No significant difference in the survey value and in the increase over base from controls.

(3) Significant differences in the survey value and in the decrease from base in comparison with controls $(\mathrm{P}<0.04)$.

(4) Daily mean intake from weekly diaries in kcal per kg body weight.

(5) Mean pre-prandial BG from weekly diaries. Values following base are all significant versus base $(\mathrm{P}<0.0001)$.

\subsection{Method of Survey}

The study consisted in a comparison between trained pairs and a number of random controls during a eight-year follow-up period. The protocol provided for 6 medical examinations after the first one, i.e. after 3 and 6 months and after 2,4,6,8 years. After an initial clinical examination anthropometric measures were taken (Ciampolini et al., 1990, 2012, 2013). Through structured interviews mothers were asked about the symptoms and the administration of antibiotics and antinflammatory medicines. Mothers reported the number of days in the last 3 months with occasional vomiting, diarrhea or abdominal aches as well as the number of days in the last month with temperature or taking of the above mentioned medicines. Besides mothers filled in a structured food diary covering 7 days (Ciampolini et al., 1990, 2012, 2013). A few children did not report for the fixed examination. The missing data were obtained on the telephone through structured interviews.

\subsection{Re-Education}

After the first short period of diarrhea stopping, the group was trained for 7 weeks under the researchers' revision. The first step was suspending meals until the child gave signs of hunger (Ciampolini et al., 1990, 2012, 2013). The claim for food might consist in a change of mood from tedious to capricious. Mothers assessed the child's initial hunger before showing (him/ her) food or a laid table. At the first request, before serving the meal, mothers were asked both to memorize the manifestations of restlessness and to measure BG. On other occasions the child himself/herself moved around in search of food or showed his/her wish with words or gestures. The first meal was postponed from 0 to 48 hours, 2 hours on average. At the following meals mothers repeated the new strategies, by soliciting energy expenditure rather than by offering new energy. Energy- giving food with 
more than $60 \mathrm{kcal} / 100 \mathrm{~g}$. was allowed initially in a limited amount but in a growing quantity after the request for food and after eating fruit or vegetables. The portion recommended was $150 \mathrm{gs}$ vegetables before lunch and dinner and 200gs fruit before breakfast. The energy-giving food was calculated in such a way as to evoke a new request before the time fixed for the following meal. After a $3-14$ day training mothers had learned how to evaluate both the energy left in circulation (BG) from the preceding meal and the one needed to cover the gap up to the time fixed for the following meal (Ciampolini et al., 1990, 2012, 2013). Mothers found a way to make the child manifest the initial hunger (request for food, $\mathrm{IH}$ ) 4 times a day before satisfying it. Each time the amount of food, the content and the time of meal could be adjusted. After few days of attempts and errors, and at times, of irregular mealtimes, mothers succeeded in obtaining the child's request/meal 3 or 4 times a day with an average error of less than 30 minutes in $90 \%$ of cases. Such alimentary rhythm is called as Recognizing Hunger or Initial Hunger Meal Pattern IHMP (Ciampolini et al., 1990, 2012, 2013). Mothers of the children belonging to the control group (53) as well as mothers of the children following the new alimentation programme were assured of the temporary nature of diarrhea and encouraged to increase outdoor physical activity.

\subsection{Statistics}

In a previous research, we encountered, a difference of 8 days \pm a standard deviation of 13 days in the means of diarrhea days between the trained group and the control one. Such difference indicated that the pattern adopted was having satisfactory results. Based on this target, the subjects needed for the study were to be at least 49 for each group compared in order to highlight a similar difference among the means with a $90 \%$ power and a 0.05 unilateral alpha. The values are indicated in means \pm standard deviation. We used Yates' test and the 2-sided Student's $t$ test on paired or non paired samples to evaluate the statistical significance of differences. The significance was set at $\mathrm{P}<0.05$ for the single comparisons (Armitage et al., 1994). All data have been reported on Microsoft Excel (Microsoft Corporation, Redmond, WA) for the statistical analyses and the presentation of results.

\section{Results}

The fifty-three control pairs and the one hundred trained subjects were of the same age. Their body weight and the percentage weight of the mean of reference (NCHS, US) for the same age were similar at the beginning of the research (Table 1). Differences in body growth between the two groups in absolute terms as well as in percentage terms were not found. Dropouts during the follow-up stage were similar while the needed data were collected on telephone. Losses of information at each assessment owing to changes of address are reported in Table 2 .

Table 2. Days with diarrhea out of previous 90 days at different times after recruitment

\begin{tabular}{|c|c|c|c|c|c|}
\hline \multicolumn{3}{|c|}{ CONTROL } & \multicolumn{3}{|c|}{ TREATED } \\
\hline Surwey & dropouts & Mean $\pm \mathrm{SD}^{1}$ & dropouts & Mean $\pm \mathrm{SD}^{1,2,3}$ & Surwey \\
\hline Base & & $49.4 \pm 26.0$ & & $47.9 \pm 24.9$ & Base \\
\hline $3 \mathrm{~m}$. & 2 & $13.1 \pm 20.4$ & 3 & $1.9 \pm 3.5$ & $3 \mathrm{~m}$. \\
\hline $6 \mathrm{~m}$. & 3 & $8.7 \pm 11.8$ & 4 & $2.0 \pm 3.7$ & $6 \mathrm{~m}$. \\
\hline $2 \mathrm{y}$. & 3 & $2.9 \pm 5.2$ & 5 & $2.2 \pm 3.7$ & $2 \mathrm{y}$. \\
\hline $4 \mathrm{y}$. & 2 & $4,1 \pm 14,0$ & 4 & $2.0 \pm 3,3$ & $4 \mathrm{y}$. \\
\hline $6 y$ & 4 & $3,6 \pm 11,7$ & 5 & $1.9 \pm 4.9$ & $6 \mathrm{y}$. \\
\hline $8 \mathrm{y}$. & 5 & $0,4 \pm 1,0$ & 7 & $1.3 \pm 3.4$ & $8 \mathrm{y}$. \\
\hline Surwey & dropouts & Mean $\pm \mathrm{SD}^{1}$ & dropouts & Mean $\pm \mathrm{SD}^{1,2,3}$ & Surwey \\
\hline \multicolumn{3}{|c|}{ CONTROL } & \multicolumn{3}{|c|}{ TREATED } \\
\hline
\end{tabular}

(1) Significant decreases from base at all surveys $(\mathrm{P}<0.001)$.

(2) Significant differences from controls at the surveys after 3 and 6 months $(\mathrm{P}<0.03)$.

(3) Significant difference in the decrease from the base(longitudinal) only at the three month survey $(\mathrm{P}<0.03)$.

The chronic diarrhea and frequent vomiting are associated during the period of high energy intake and of high pre-prandial BG, i.e. when the energy taken in previous meals is not completely consumed. The situation changes by adopting an alimentary pattern based on the recognition of initial hunger (Initial Hunger IH, and IH Meal Pattern IHMP). During each data collection we examined the changing of intake and symptoms by using 3 types of statistical analysis. We compared survey values with the basal values and carried out two comparisons between the trained group and the control group i.e. we compared the absolute survey values and the survey 
differences with the base values. The daily mean energy intake per kg body weight was calculated from diary reports (Table 1). Each survey highlighted a lower intake by the trained children as compared to controls (P from $<0.04$ to $<0.0001$ ). Consistently, the mean weekly value of pre-prandial BG (trained children only) was significantly lower than at the beginning of the study $(\mathrm{P}<0.0001)$. After recruitment, days with diarrhea and vomiting significantly diminished both in the trained group and in the control one (Tables 2 and 3). However, the numbers of days with fever and of days with administration of antibiotics or anti-inflammatory substances (drugs) decreased from recruitment in trained children at all surveys; in control children, fever significantly decreased after two years from recruitment and at subsequent 3 surveys. Drug administration decreased only at the survey after 2 years from recruitment.

Table 3. Days with vomiting out of previous 90 days

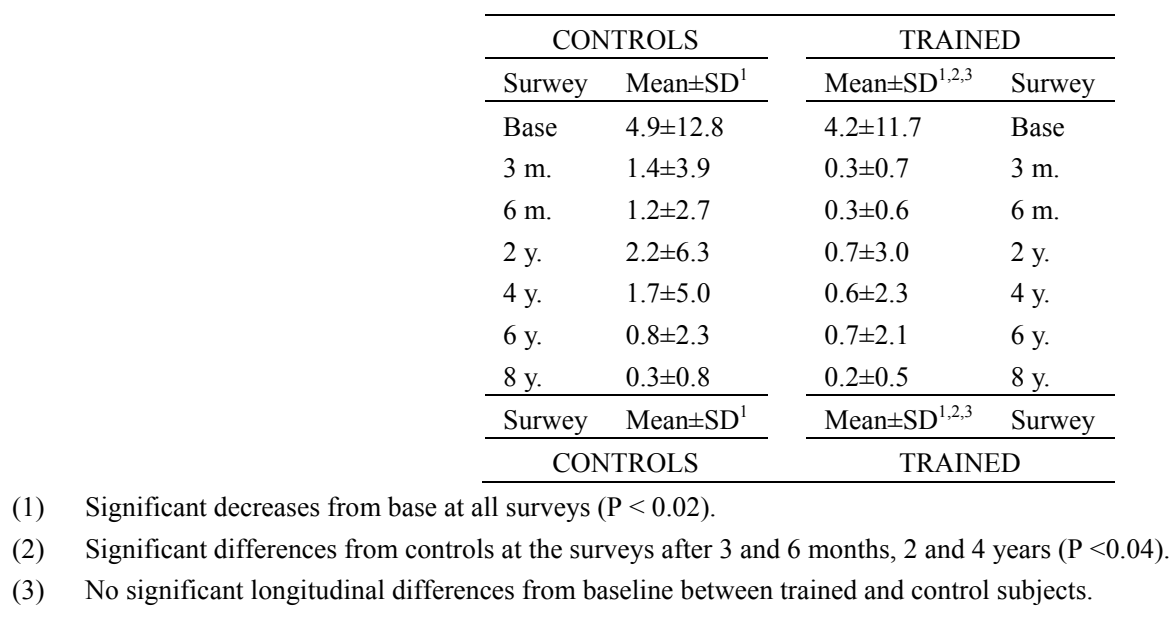

Comparing the control group with the trained one at each survey, significantly lower values of diarrhea are found in the trained subjects up to the second year. In all 6 surveys, the value in the trained subjects remains lower (compared with the control group) in 5 out of 6 comparisons (Table 3). The Chi Square test for trend points out a significant difference $(\mathrm{P}<0.05)$. As regards vomiting, significantly lower values are observed in trained children up to four years of age. As far as days with fever and days with drug adninistration are concerned, the trained group turned out to be less feverish after six years from the start of the study.

The difference between trained and control children having a scientific value of demonstration concerns the reduction from base values. Energy intake reductions are significantly larger in trained than in control subjects at all 6 surveys after recruitment $(\mathrm{P}<0.04)$, days with diarrhea only after 3 months, drug administration at the surveys after 2 years and after 8 years.

\section{Discussion}

The current results (Tables 1, 2 and 3) confirm what already published by the international scientific press. Chronic diarrhea and frequent vomiting occur during periods of high energy intake and high pre-prandial BG levels, i. e. when the energy previously taken is not completely expended. In adults, this condition is known as fattening/insulin resistance, The situation changes by adopting an alimentary behaviour based on the recognition of Initial Hunger (IHMP) that is associated at every age to a significant decrease of energy intake and a low BG level before meals (Ciampolini et al., 2010, 2006, 2011, 2011, 2010, 2012, 1990, 2012, 2013). In adults the IHMP and the low BG concentration are associated to a high insulin sensitivity. Allegedly children should be trained to follow this pattern (IHMP) in order to become high insulin sensitive adults.

The research has been carried out on clinically healthy children with a temporary functional disorder so the usefulness of every intervention was doubtful before this investigation. Diarrhoeic children have thinner skinfolds (a thinner subcutaneous layer) compared with the normal reference (NCHS, US) (Ciampolini et al., 1990, 2012, 2013). Thinness does not depend on the diarrhoeic condition, it is rather family related (Cooper et al., 2014; de Graf et al., 2004). According to the present study, diarrhoeic children (2 years old) reach a standard average body weight (for their age) at about 4 years (Table 1), but maintain a low basal insulin level and show a scarce development of the subcutaneous layer (Cooper et al., 2014; de Graf et al., 2004). This means that at 4 - 6 years children develop more lean mass than normal children do (Cooper et al., 2014). On the other hand the 
scarce development of the subcutaneous layer entails a precocious limit to energy accumulation. Chronic diarrhoeic children require that a high attention is given to achieve an even balance of meals. BG becomes oxidized earlier than other nutrients until its total expenditure (Elliott et al., 2002; Borg et al., 2011; Matsuda et al., 1999; Wiesli et al., 2004), and we use BG as an index of the energy available in circulation. These notions recommend mothers to assess the energy supply at each meal to barely get over the inter-meal period without the onset of hunger (IH). This even balance does not coincide with a steady pre-prandial BG level but with a low BG at the same physiological conditions (i.e., before meals). A high pre-prandial BG fosters fattening/insulin resistance even if steady. A low pre-prandial BG is a necessary as well as a sufficient condition to have an even energy balance (homeostasis) (Ciampolini et al., 2011, 2013; Fisher et al., 2002).

We studied 24 similar infants by food diaries, indirect calorimetry and doubly labelled water before and after training IHMP (Ciampolini et al., 1990, 2012, 2013). The resting metabolic rate and the total energy expenditure confirmed the energy intake that mothers reported in food diaries, and explained a $15.5 \%$ pre/post difference in energy intake. Another 3\% - $4 \%$ was explained by lower energy fecal loss (Ciampolini et al., 2001). In this study the non-specific diarrhea appears as a temporary disorder typical of the second year of life, due to disappear automatically. The stopping of diarrhea in the control group does not imply recovery of health. The huge increase in total daily energy metabolism, in resting metabolic rate, in energy malabsorption, in BG as index of energy availability suggests a heavy education to the adults' fattening/insulin resistance that, in their turn, are associated to the development of sterile inflammation. The overall sterile inflammation or pro-inflammatory state represents one of the most important notions acquired by medical physiopathology in the last century (Brandtzaeg et al., 1989; Hecht et al., 2007; Festa et al., 2000; Reaven 2006; Smith 2007; Bigorgne et al., 2008; Cani et al., 2007; Stratton et al., 2000; Bruun et al., 2003; Davidson et al., 1984; Van der Waaij et al., 2008; Sartor, 2008). Such a state is associated both to increased vascular, autoimmune and tumor risks but also to degenerative and functional disorders (Ciampolini et al., 1990, 2006, 2010, 2010, 2011, 2012, 2012, 2013, 2013, 2013, 2013, 2014; Fisher \& Birch., 2002). In addition it facilitates the onset of autoimmune and allergic diseases like arthritis and eczema. In the last 50 years there has been an increase in the number of children affected by asthma, autism, congenital malformations, dyslexia, attention deficit, hyperactivity, schizophrenia, obesity and diabetes. The US researchers have tried to find out the causal factors by planning the National Children's Study (NCS, Landrigan, 2015). The Children's Health Act allowed an epidemiological study involving 100000 children from birth up to 21 years of age. On December $12^{\text {th }} 2014$ Francis Collins, director of the National Institute of Health (NIH) decided to put an end to the NCS by claiming that "the study was not feasible in its originary design".

\section{Conclusion}

The level of energy (i.e. of glucose, fats, proteins) in circulation and in tissues should not be the highest possible, but optimal. We taught how to recognize the correspondence between the subjective sensation of hunger (trend with hunger at meals, AFP or IHMP) and the BG. The aim was both to obtain, meal by meal, a low pre-prandial BG concentration and, thanks to the skill acquired, to curb fattening/ insulin resistance. The optimal energy intake corresponded to a low BG level before meals that turned out to be the same in several studies carried out on different subjects (about $76.6 \pm 3.7 \mathrm{mg} / \mathrm{dL}$ in sedentary people). Such level can be easily maintained after a two-week training of BG measurements (Initial Hunger). Ignoring Initial Hunger may contribute to increase in children asthma, autism, congenital malformations, dyslexia, attention deficit, hyperactivity, schizophrenia, obesity and diabetes (37). A new formulation of the National Children's Study (NCS, US) should both highlight the current ignorance between a subjective sensation of hunger and the BG and plan a new awareness of the relationship between hunger sensation and meals. Developing such awareness is within the population's reach. At recruitment a remarkable minority of (untrained) children showed pre-prandial BG concentrations alike those of children whose mothers had been trained not to offer food (12).

\section{Acknowledgements}

The here summarized research was supported by the Italian Ministry of University, Research, Science and Technology grants for the years 1998-2002 and by ONLUS Nutrizione e Prevenzione, Firenze, for the years 2003-2015. No conflicts of interest.

The Author acknowledges the indispensable collaboration with David Lowel-Smith (NZ) and Riccardo Bianchi (NY), and the strategic, statistical support by Cutberto Garza (Boston, US), Giuliano Parrini (professor of physics, Firenze, Italy) and Andrea Giommi (Professor of Statistics, Firenze, Italy).

\section{References}

Armitage, P., \& Berry, G. (1994). Statistical Methods in Medical Research (3rd Ed.). Blackwell, Oxford, UK. 
Bigorgne, A. E., Bouchet-Delbos, L., Naveau, S., Dagher, I., Prévot, S., Durand-Gasselin, I., ... Perlemuter, G. (2008). Obesity-induced lymphocyte hyperresponsiveness to chemokines: a new mechanism of fatty liver inflammation in obese mice. Gastroenterology, 134, 1459-1469. http://dx.doi.org/10.1053/j.gastro.2008.02.055

Borg, R., Kuenen, J. C., Carstensen, B., Zheng, H., Nathan, D. M., Heine, R. J., ... ADAG Study Group. (2011). $\mathrm{HbA}_{1}(\mathrm{c})$ and mean blood glucose show stronger associations with cardiovascular disease risk factors than do postprandial glycaemia or glucose variability in persons with diabetes: the A1C-Derived Average Glucose (ADAG) study. Diabetologia, 54(1), 69-72. http://dx.doi.org/10.1007/s00125-010-1918-2

Brandtzaeg, P., Halstensen, T. S., Kett, K., Krajci, P., Kvale, D., Rognum, T. O., ... Sollid, L. M. (1989). Immunobiology and immunopathology of human gut mucosa: humoral immunity and intraepithelial lymphocytes. Gastroenterology, 97, 1562-1584.

Bruun, J. M., Verdich, C., Toubro, S., Astrup, A., \& Richelsen, B. (2003). Association between measures of insulin sensitivity and circulating levels of interleukin-8, interleukin-6 and tumor necrosis factor-alpha. Effect of weight loss in obese men. European Journal Endocrinology, 148(5), 535-42. http://dx.doi.org/10.1530/eje.0.1480535

Ciampolini, M., Vicarelli, D., \& Seminara, S. (1990). Normal energy intake range in children with chronic non-specific diarrhea. Association of relapses with the higher level. Journal Pediatric Gastroenterology and Nutrition, 11, 342-50. http://dx.doi.org/10.1097/00005176-199010000-00010

Ciampolini, M., Bini, S., Giommi, A., Vicarelli, D., \& Giannellini, V. (1994). Same growth and different energy intake in chronic non-specific diarrhea children in a four-year period. International Journal Obesity, 18, $17-23$.

Ciampolini, M., Borselli, L., \& Giannellini, V. (2000). Attention to metabolic hunger and its effects on Helicobacter pylori infection. Physiology \& Behavior, 70, 287-296. http://dx.doi.org/10.1016/S0031-9384(00)00273-0

Ciampolini, M., Giannellini, V., \& Butte, N. (2001). Recognition of depletion manifestations (bearable hunger) in infants by trained caregivers and lower fecal energy loss (abstract). SSIB annual meeting, Philadelphia (USA).

Ciampolini, M., \& Bianchi, R. (2006). Training to estimate blood glucose and to form associations with initial hunger. Nutrition and Metabolism (London) 3, 42. http://dx.doi.org/10.1186/1743-7075-3-42

Ciampolini, M., Lovell-Smith, D., \& Sifone, M. (2010). Sustained self-regulation of energy intake. Loss of weight in OW subjects. Maintenance of weight in normal-weight subjects. Nutrition and Metabolism (London), 7, 1-4. http://dx.doi.org/10.1155/2010/286952

Ciampolini, M., \& Sifone, M. (2011). Differences in maintenance of mean Blood glucose (BG) and their association with response to "Recognizing Hunger". International Journal of General Medicine, 4, 403-412. http://dx.doi.org/10.2147/IJGM.S19035

Ciampolini, M., Lovell-Smit, D., Bianchi, R., de Pont, B., Sifone, M, van Weeren, M., ... Pietrobelli, A. (2010). Sustained self-regulation of energy intake. Initial hunger improves insulin sensitivity. Journal Nutrition and Metabolism, Article ID 286952. http://dx.doi.org/10.1155/2010/286952

Ciampolini, M. (2011). Meal by meal dynamic balance of energy in blood. Research Signpost, 37/661(2), Vazhappalli Jn., Fort Post Office, Trivandrum-695 023, Kerala, INDIA. ISBN: 978-81-308-0457-6.

Ciampolini, M. (2012). Eliciting Clear-Cut Initial-Hunger at Proper Time. OMICS Publishing Group: http://dx.doi.org/10.4172/2161-1017.1000102

Ciampolini, M. (2012). Requested meals versus scheduled meals. International Journal General Medicine, 5 , 1-9. http://dx.doi.org/10.2147/IJGM.S29889

Ciampolini, M. (2013). Interruption of automatic feeding, of fattening and associated immune deficiency. Recent Research. Developments 9, Nutrition. Kerala, INDIA ISBN: 978-81-308-0519-1. Retrieved from http://www.ressign.com/UserBookDetail.aspx?bkid=1337\&catid=291

Ciampolini, M., Lovell-Smith, H., D., Kenealy, T., \& Bianchi, R. (2013). Hunger can be taught: IHMPregulates eating and improves energy balance (Review). International Journal General Medicine, 6, 465478. http://dx.doi.org/10.2147/IJGM.S40655 
Ciampolini, M., Brenna, J., T., Giannellini, V., \& Bini, S. (2013). Interruption of scheduled, automatic feeding and reduction of excess energy intake in toddlers. International Journal General Medicine, 6, 39-47. http://dx.doi.org/10.2147/IJGM.S39946

Ciampolini, M., \& Lovell-Smith D. (2014). Recognising Hunger. Self-Regulation of Food Intake and Energy Balance. A Handbook. Lambert Academic Publishing, Germany. Retrieved from https://www.lap-publishing.com/.../978-3-8473-7027-7, 9783847370277, 3847370278

Cooper, I. F., \& Siadaty, M. S. (2014). 'Bacteriums' associated with 'Blood Glucose Level Finding': Top Publications. Bio Med Lib Review, 6, 26.

Davidson, G. P., Robb, T. A., \& Kirubakaran, C. P. (1984). Bacterial contamination of the small intestine as an important cause of chronic diarrhea and abdominal pain: diagnosis by breath hydrogen test. Pediatrics, 74(2), 229-235.

de Graaf, C., Blom, W. A. M., Smeets, P. A. M., Stafleu, A., \& Hendriks, H. F. J. (2004). Biomarkers of satiation and satiety. American Journal of Clinical Nutrition, 79, 946-961.

Delmée, E., \& Cousin, B. (2007). Metabolic endotoxemia initiates obesity and insulin resistance. Diabetes, 56, 1761-1767. http://dx.doi.org/10.2337/db06-1491

Gavin, J. R. (2001). Pathophysiologic mechanisms of postprandial hyperglycemia. American Journal Cardiolology, 88, S4-S8. http://dx.doi.org/10.1016/S0002-9149(01)01830-6

Elliott, S. S., Keim, N. L., Stern, J. S., Teff, K., \& Havel, P. J. (2002). Fructose, weight gain, and the insulin resistance syndrome. American Journal Clinical Nutrition, 76, 911-922.

Festa, A., D’Agostino, R. Jr., Howard, G., Mykkanen, L., Russell, P. T., \& Haffner, S. M. (2000). Chronic subclinical inflammation as part of the insulin resistance syndrome: the Insulin Resistance Atherosclerosis Study (IRAS). Circulation, 102, 42-47. http://dx.doi.org/10.1161/01.CIR.102.1.42

Fisher, J. O., \& Birch, L. L. (2002) Eating in the absence of hunger and overweight in girls from 5 to $7 \mathrm{y}$ of age. American Journal of Clinical Nutrition, 76, 226-231.

Hecht, G. (2007). In the beginning was Helicobacter pylori: roles for microbes in other intestinal disorders. Gastroenterology, 132(2), 481-483. http://dx.doi.org/10.1053/j.gastro.2007.01.013

Landrigan, P. J., \& Baker, B. (2015). The National Children's Study — End or New Beginning? New England Journal Medicine, 372, 1486-1487. http://dx.doi.org/10.1056/NEJMp1500276

Matsuda, M., \& DeFronzo, R., A. (1999). Insulin sensitivity indices obtained from oral glucose tolerance testing: comparison with the euglycemic insulin clamp. Diabetes Care, 22, 1462-1470. http://dx.doi.org/10.2337/diacare.22.9.1462

Reaven, G. M. (2006). The metabolic syndrome: is this diagnosis necessary? American Journal Clinical Nutrition, 83, 1237-1247.

Sartor, B. (2008). Microbial influences in inflammatory bowel disease. Gastroenterology, 134(2), 577-594. http://dx.doi.org/10.1053/j.gastro.2007.11.059

Smith, C. W. (2007). Diet and leukocytes. American Journal Clinical Nutrition, 86, 1257-1258.

Stratton, I. M., Adler, A. I., Neil, H. A. W., Matthews, D. R., Manley, S. E., Cull, C. A., ... Holman, R. R. (2000). Association of glycaemia with macrovascular and microvascular complications of type 2 diabetes (UKPDS 35): prospective observational study. British Medical Journal, 321, 405-412. http://dx.doi.org/10.1136/bmj.321.7258.405

Van der Waaij, L. A., Limburg, P. C., Mesander, G., \& van der Waaij, D. (1996). In vivo IgA coating of anaerobic bacteria in human faeces. Gut, 38(3), 348-354. http://dx.doi.org/10.1136/gut.38.3.348

Wiesli, P., Schaffler, E., Seifert, B., Schmid, C., \& Donath, M. Y. (2004). Islets secretory capacity determines glucose homoeostasis in the face of insulin resistance. Swiss Med Wkly, 134(37-38), 559-564.

\section{Copyrights}

Copyright for this article is retained by the author(s), with first publication rights granted to the journal.

This is an open-access article distributed under the terms and conditions of the Creative Commons Attribution license (http://creativecommons.org/licenses/by/3.0/). 